weight is approached by a series of progressive steps in size, there is every possibility that it will ultimately prove successful. Given a steady and well-organised progress, helped forward by the technician as well as by the business man, there is fair ground for the belief that aviation will become a very important factor in the world's commerce, and lead to results which would have been impossible with the older and slower means of transit.

E. F. R.

\section{THE "TIMES" WEATHER REPORTS.}

M ETEOROLOGY in this country has owed much to the enterprise of the Press. In the year 1876 the Times inaugurated the service of evening telegrams to the Meteorological Office, and for several years it bore the expense thereof, at first alone, and afterwards in conjunction with the Standard and the Daily Neres. It was not until r 880 that the cost of this part of our national weather service was taken over by the Government. After relinquishing its direct connection with the enterprise, the Times continued to stimulate public interest in meteorology by including in its pages a copy of the evening weather chart of the Meteorological Office. Upon the outbreak of war publication had to be discontinued, but the issue for January 22 was marked by the revival of this very welcome feature. We are glad also to note that the editor has seen his way to increase the scale of the map, which now occupies the width of two columns of the paper, the change making a vast difference to its effectiveness. It is also of interest to note that the isobars are marked in millibars, as well as in inches, the intervals between them being five millibars. We hope that the day may not be far distant when the blank spaces may be filled by observations. Ships' observations from the Atlantic should soon be available again by wireless, and it seems not too much to expect that these and the French reports may reach this country sufficiently early for incorporation in the map.

Just as in 1876 the Times inaugurated the evening weather service, so now it takes the lead in another new departure by publishing a special aviation report. This new section summarises in tabular form the observations of upper winds represented on maps in the special edition of the Daily Weather Report of the Meteorological Office, which has only recently been released from the censor's ban, and supplements it with a section on "Flying Prospects for the Day." Civilian flying and commercial aviation will be realities very shortly, and then reports such as these will have a very real practical interest for a considerably wider circle of readers than the actual aviators. We can imagine would-be passengers scanning the upper air report with an even closer interest than they have in the past bestowed on forecasts of Channel crossings, and that not merely from the point of view of their comfort or discomfort during the flight, for the velocity and direction of the wind must obviously affect the time required for a given journey, just as it did in the old days of sailing-vessels.

Another new and interesting feature of the reports is an adaptation of the forecast for southern England to the peculiar local conditions of the London area.

\section{PITCHBLENDE ORE IN DEVON.}

THE Times of January 18 reports the discovery of a fine lode containing pitchblende on the Kingswood estate, Buckfastleigh, South Devon, and quotes an analysis of what is stated to be a representative sample of the ore, which shows a uranium oxide content of more than 26 per cent. This is the first time that pitchblende ore has been recorded from Devon. The precise location of the lode is not stated, but Kingswood is situated upon shales of Upper Devonian age, and just outside the area to which the metamorphism caused by the Dartmoor granite has extended. North of Kingswood there are several copper lodes that course in a general east-to-west direction, underlie south, and contain mixed sulphide ores. These were the only lodes hitherto known in the district. Uranium ores where they exist in Cornwall are associated with copper.

In Cornwall the ores of uranium have long been worked at South Terras Mine, near St. Austell, and at Wheal Trenwith, St. Ives, the total output since 1884 being nearly I 500 tons. The ore has also been recorded from many other Cornish mines, notably Crow Hill, St. Austell Consols, Egloshellan, Tresavean, Wheals Gorland, Buller, Unity, and Basset, and at Tincroft, South Crofty, and Dolcoath.

At South Terras the ores associated with pitchblende are nickel, cobalt, and bismuth, and such minerals as kaolin and fluorite. Near the surface the phosphates autunite and torbernite occurred, but gave place at depth to pitchblende of two qualities-namely, "green ore " and "dark ore" -which are reported in a prospectus issued by the Radium and Uranium Syndicate, Ltd., to have contained 6.2 per cent. and 36 per cent. respectively of uranium oxide. The lodes trend north and south, but the pitchblende was confined to a leader, and mostly to the walls of the leader. In the mode of occurrence and associated minerals the lodes show a close resemblance to those worked at Joachimsthal, in Bohemia, and it is held generally that the contents of both groups have been derived from emanations given off during granite intrusions.

It may be mentioned that the principal sources of uranium oxides lie in Portugal and Bohemia, and that the ores from the former country contain on an average about $\mathrm{I}$ per cent. of $\mathrm{UO}_{3}$. In America rooo tons of ore recently yielded 70 tons of concentrate, which contained only 3 per cent. of $\mathrm{U}_{3} \mathrm{O}_{8}$.

Further developments at Kingswood will therefore be awaited with interest, especially in view of the statements made as to the abnormal richness of the ore in uranium oxides.

NO. 2570 , VOL. IO2] 